\title{
Missed expectations: teacher and coach tensions at the boundary of STEM integration in an elementary classroom
}

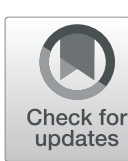

Justin McFadden ${ }^{1 *}$ and Gillian Roehrig ${ }^{2}$

\begin{abstract}
The current study explored how a STEM coach supported an elementary teacher during the implementation of an integrated curriculum that culminated with an engineering design challenge. The findings of the case study reported, detail how the reflective nature of the coaching moves employed failed to fully meet the needs of the teacher given the distinct challenges that arose upon implementation of the co-developed curriculum. By closely examining two primary data sources: (1) five extended coaching sessions, and (2) the coach's pre-post coaching log reflections; analysis identifies and explores how the pair's missed expectations produced unanticipated tensions that hindered the potentials of the teacher-coach relationship. Insights related to an elementary teacher's conceptions of STEM integration are also revealed within the data presented. Finally, analysis enabled discussion of strategies that might be employed to strategically support elementary teachers working with coaches; specifically exploring how differentiated supports based on prior experiences might be instituted.
\end{abstract}

Keywords: STEM integration, Coaching, In-service teacher learning, Science education reform

\section{Introduction}

Coaching for instructional change

The push for instructional change in both science and mathematics education continues to present barriers for classroom teachers in large part because reform-based teaching greatly contrasts accustomed, "typical" classroom instruction (Anderson et al., 2018; Gibbons \& Cobb, 2017; McFadden, 2019). At the elementary level, mathematics and science coaches have been used to ease teachers' transitions as proposed changes get translated into actual classroom practice (Giamellaro \& Siegel, 2018). Elementary teachers have traditionally received coaching support in other content areas; most notably literacy (Ippolito, 2010) and mathematics (Bengo, 2013), with science emerging more recently (Anderson, Feldman, \& Minstrell, 2014; Laxton, 2016). Given current

\footnotetext{
* Correspondence: Justin.mcfadden@louisville.edu

${ }^{1}$ College of Education and Human Development, University of Louisville,

1905 South 1st Street, Louisville, KY 40292, USA

Full list of author information is available at the end of the article
}

accountability pressures associated with both literacy and mathematics (Banilower et al., 2018; Griffith \& Scharmann, 2008), elementary teachers have historically received more support within these content areas, consequently increasing comfort and therefore coverage. Concurrently, elementary teachers have not received science-focused professional development (Banilower et al., 2013; Trygstad, 2013), which gets further confounded when considering the sparsity of science courses teachers take prior to entering the field (Bullough et al., 2002; Olson, Tippett, Milford, Ohana, \& Clough, 2015). In brief, the field will continue to need supports, including professional development (Van Driel, Beijaard, \& Verloop, 2001) and coaching (Lofthouse, 2019), for in-service elementary teachers especially given expectations to implement new standards call not only for reform-based instruction, but also integrated science/mathematics (Bybee, 2010; Moore, Tank, Glancy, \& Kersten, 2015).

\section{Springer Open}

(๑) The Author(s). 2020 Open Access This article is licensed under a Creative Commons Attribution 4.0 International License, which permits use, sharing, adaptation, distribution and reproduction in any medium or format, as long as you give appropriate credit to the original author(s) and the source, provide a link to the Creative Commons licence, and indicate if changes were made. The images or other third party material in this article are included in the article's Creative Commons licence, unless indicated otherwise in a credit line to the material. If material is not included in the article's Creative Commons licence and your intended use is not permitted by statutory regulation or exceeds the permitted use, you will need to obtain permission directly from the copyright holder. To view a copy of this licence, visit http://creativecommons.org/licenses/by/4.0/. 


\section{Research rationale}

The field would benefit from more nuanced and intricate studies that exemplify how coaches interact with elementary teachers around science and integrated science, technology, engineering, and mathematics [STEM] teaching, as well as explorations into teachers' perceived value of a coach's role while promoting change (Campbell \& Malkus, 2011; Desimone \& Pak, 2017; Jacobs, Boardman, Potvin, \& Wang, 2018). Limited research exists that investigates how coaches navigate simultaneous pressures (e.g. school-based versus teacher-based goals) while developing a teacher-coach relationship. The current study therefore examined a 4th grade science teacher and her STEM coach during an entire school year while implementing a codesigned, STEM-integrated curriculum.

Historically, experienced and/or successful classroom teachers were assigned coaching roles as school districts attempted to recast teachers' roles without necessarily affording them positional authority that an administrator might hold (Coburn \& Woulfin, 2012; Ippolito, 2010). And while ample research that details what coaches do is emerging, limited studies actually examine how they do it (Laxton, 2016; Robertson, Ford-Connors, Frahm, Bock, and Paratore (2019). Furthermore, Desimone and Pak (2017) have recently recommended more in-depth inquiries into coaching models, specifically by asking how, when, and why questions. The following research question therefore guided the current study: How does a reflective-based coaching model support an elementary teacher's implementation of a STEM-integrated unit during a year-long, job-embedded professional development experience?

\section{Literature review Coaching roles}

Coaches, whether in the fields of literacy (c.f. Gibbons \& Cobb, 2017), mathematics, or science, have been utilized to help teachers break routines deemed most difficult to change (Coburn \& Woulfin, 2012). As a result, coaches inevitably provide teachers with necessary feedback concerning practice, something less understood in the literature (Mangin \& Dunsmore, 2015). In addition to navigating the complexity of teaching and learning in the classroom, coaches must also strive for teacher development and change, which involves praising teacher performance and building potentially new conceptual understandings while simultaneously identifying areas for improvement (Campbell, 1996; Lofthouse, 2019). Despite the rapid influx of STEM-specific, coaching related supports in schools, limited research exists that closely examines the full enactment of a coach's role (Giamellaro \& Siegel, 2018). Anderson et al. (2014) identified teacher trust as a key prerequisite for furthering a given coachteacher relationship, though this finding emerged via interview analysis rather than examination of actual coaching conversations. In practice, coaches typically learn about and actually define their role while the work itself occurs (Lord, Cress, \& Miller, 2008). More recently, calls for coaches to intentionally engage teachers in "sense-making events" have occurred primarily because it pushes and enables them to reorganize their initial thinking and beliefs (Ketelaar, Beijaard, Boshuizen, \& Den Brok, 2012; Laxton, 2016; Robertson et al., 2019). Supplanting and maintaining instructional change can unfortunately fail as "surface level" changes get reported, rather than actual teacher learning and growth (Coburn, 2004; Spillane, 2000).

More often, coaches spend too much time catering to administrative needs (e.g. materials management) than actually coaching, denying them the necessary time needed to develop a fruitful relationship (Campbell \& Malkus, 2011; Fullan \& Knight, 2011). Further complicating matters, Mangin and Dunsmore (2015) recently reported coaches struggle to directly critique "inadequate teaching practice" despite being distressed when witnessing it occur. Moreover, coaches have reported limited capacity to leverage their own expertise when judging a corresponding teacher's practice (Gibbons, Kazemi, \& Lewis, 2017). Clearly the aforementioned research is just beginning to recognize the importance of initiating and building a sound teacher-coach relationship, a task that actualizes one's role via the supports provided.

\section{Teacher-coach relationships}

Coaching conversations can spark strong responses and uncomfortable experiences primarily because the process is grounded in one person's actions within the classroom, something nontrivial and deeply personal (Cohen \& Hill, 2008; McFadden, 2019). Furthermore, it should not be surprising that "the act of analyzing one's actions, decisions, or products by focusing on our process of achieving them" (Killion \& Todnem, 1991; p. 15) might position a coach in problematic territory given the underlying premise insinuates individual change is needed; a reality that may result in teacher resistance (Jacobs et al., 2018). In brief, reflective practice should ultimately strive for "constructive dialogue, [while] viewing issues and events from different perspectives, generating ideas, solving problems, managing and learning from conflict, and making decisions" (York-Barr, Sommers, \& Ghere, 2006; p. 159). It is within these boundaries that coaches must carve out their role (Gallucci, Lare, Yoon, \& Boatright, 2010) and develop a productive relationship by enacting relational strategies that promote teacher learning, oftentimes while being viewed as the "expert" (Mudzimiri, Burroughs, Luebeck, Sutton, \& Yopp, 2014) and despite receiving 
minimal initial training and ongoing support (Gallucci et al., 2010).

\section{Theoretical framework}

More recent and foundational research suggests teacher's translation of requests for instructional change should not be viewed in a straightforward manner because during the process they regularly receive various reformbased "messages" (Coburn, 2001; Spillane, Hopkins, \& Sweet, 2017; Spillane, Reiser, \& Reimer, 2002; Weick, 1995). If attempted without necessary support, this interpretation process can be troublesome for individual teachers, particularly when change requests provoke fear of failure and consequently feelings of anxiety. Given the aim of requests to improve instruction also encompass the need for teachers to construct new understandings and develop personal expertise; instructional supports (i.e. coaches) can be employed to alleviate any tensions that may arise during this process. Coaches that support teachers striving to make instructional transitions engage in astoundingly complex work. Typically, this work is associated with broader (i.e. district or state-wide) reform efforts wherein coaches become positioned to support the onset of new teaching strategies in the classroom (Coburn \& Woulfin, 2012).

Coaches therefore become important when new policy or strategies are introduced because they help teachers "construct a plausible sense" (Weick, Sutcliffe, \& Obstfeld, 2005) of any proposed change. Stated differently, coaches often attempt to "normalize the breach" (Weick et al., 2005) for teachers by linking and integrating the old with the new. Coaching today, as a form of guided reflection (Dewey, 1933; Schön, 1987), primarily positions coaches on the "boundaries" (Star \& Griesemer, 1989) of desired change. When examined within the larger framework of current science education reform, reflective-based coaching with individual teachers should produce tensions as "what is and what ought to be" (Tatar, 2007, p.415; emphasis original) become the main emphasis of highly personalized one-on-one conversations.

\section{Reflective-based coaching}

Reflective-based coaching, grounded in aspects of cognitive coaching, typically position coaches as "mediators" (Costa \& Garmston, 1994). Coaches usually encompass this role after a teaching event or events by helping a teacher reflect on the effectiveness of a teaching strategy or lesson design idea using mutually-defined "measures of success" (York-Barr et al., 2006). During a reflectivebased coaching conversation, both participants should strive for genuine dialogue and "radical honesty" (Knight, 2007) as faults and personal shortcomings are jointly displayed, discussed, and potentially alleviated. When instituted for promoting instructional growth (e.g.
Chia, 2000), a coach must facilitate conversations focused on praxis by asking questions regarding the application of a teacher's knowledge and skills in the classroom as well as the resources available that might offer support (Osterman \& Kottkamp, 1993). Finally, a teacher-coach relationship focused on true partnership materializes when both individuals believe they can learn from one another (i.e. reciprocity; Knight, 2007) - an outcome that requires active listening by both parties.

\section{Research methods}

\section{Project overview}

The study's overarching context resides within a federallyfunded project (DUE-1238140) centered in a large metropolitan area in the midwestern United States. The project, in partnership with two urban and one suburban school district, aimed to facilitate teacher learning (grades 4-8) that coincided with the development of engineeringbased, curricular units following Moore et al.'s (2014) Framework for Quality K-12 Engineering Education and Understanding by Design (Wiggins \& McTighe, 1998, 2011). Teacher learning focused on instructional strategies connected to data measurement and analysis, as well as science content embedded within an integrated unit. A robust, ongoing coaching model (i.e. monthly coaching sessions) was also implemented as a means for supporting these broader, project targets once individual teachers returned to their classrooms - with the aim of ultimately impacting student learning (Yoon, Duncan, Lee, Scarloss, \& Shapley, 2007).

\section{Project-associated coaching model}

Coaches were introduced to the blended coaching model during a two-day workshop prior to the project's threeweek summer start date. Additionally, two graduatelevel courses were provided as coaches continued their coaching work throughout the school year; the first related to reflective-practice/instructional coaching (Costa \& Garmston, 1994; York-Barr et al., 2006) and the other STEM-integrated curriculum design. During the coaching course, participants completed assignments tied to their coaching work and participated in "just-in-time" learning centered on the coaching model and their own efforts supporting teachers' implementation of the STEM-integrated unit they had co-developed.

As a means of further supporting coaches' implementation of the coaching model, resources drawn from the blended model were also introduced and promoted. Depending on when the coaching session took place (i.e. prior to or after instruction), these resources followed a fairly set structure and also included potential coaching questions to ask. For example, one tool provided coaches with questions (e.g. what goal(s) are we aiming for today?) that resided under one of the following categories: 
(a) setting a goal, (b) explaining a process or action, (c) describing success, and (d) determining evidence of progress. A related tool with additional questions can be found in Appendix 1 (Reflecting Forward/Planning Conversations; York-Barr et al., 2006). In line with reflective practice, coaches were also taught how to be active listeners, which included strategies such as paraphrasing. This specific coaching model was developed and used because project/ school leadership recognized that coaches associated with the project would end after a single academic year.

\section{Classroom context and participants}

Data collection occurred prior to and throughout the school year in in a 5th grade classroom (students aged 10-11 years old) in a school that promotes postsecondary, college readiness for all students and has multiple partnerships with the area's largest university. The school's demographics were as follows: Asian American 63\%, African American - 24\%, Hispanic American - 10\%, and Caucasian American - 4\%. Additionally, one-third of students were English Language Learners and 75\% of students were eligible for free or reduced-price lunch.

Sammy, ${ }^{1}$ the teacher-of-interest had been teaching for 11 years; three in her current school as a science specialist: meaning she only taught science within multiple elementary classrooms. During the project, and for the first time, 5th grade was part of her STEM "rotation". Three years prior to data collection, she taught some of her current 5th graders in 2nd grade as their science teacher. Sammy represented a unique case worthy of further inquiry (Patton, 2002) due to her role as a science specialist at her school (Marco-Bujosa \& Levy, 2016) and because she had previously been coached within her school. Additionally, she demonstrated a willingness to vocalize her views and opinions with myself, as well as her coach throughout the project, which revealed an overall confidence in ability oftentimes absent with elementary teachers (c.f. Metz, 2008). Of note, she had started her post-secondary education wanting to be an engineer; ultimately switching to elementary education, which I also considered when purposefully selecting Sammy out of a potential pool of eight other teacher-coaching pairings.

During data collection Sammy's coach (Nick) had 2 years of coaching experience given he had also coached two groups of teachers the previous year of the project. Due to this prior experience as a coach, he had worked in the same school district Sammy taught in, though not in the same school. Sammy met Nick during the project's three-week professional development experience as they co-developed a STEM-integrated curriculum culminating with an engineering design challenge (EDC; McFadden \& Roehrig, 2017). During this time, Sammy

\footnotetext{
${ }^{1}$ All names are pseudonyms
}

was introduced to the aforementioned coaching model and provided opportunities to ask questions concerning it; though none were asked.

\section{STEM-integrated unit}

The unit Sammy and Nick co-developed (with two other elementary teachers not featured here) concluded with an authentic design/build that required students to successfully move an all-terrain rescue vehicle across varying surfaces (e.g. water, ice, and sand) in order to save stranded victims. Students needed to test and consider how various forces (i.e. friction) would impact the vehicle's motion given the design choices they needed to make and subsequently test. In brief, the unit began with multiple "science-based" lessons (i.e. pulling a friction "sled") that aimed to develop students' conceptual understandings of force and motion prior to designing, building, and testing the effectiveness of their vehicle. Mathematics lessons (i.e. data measurement/analysis) also occurred midway through the unit. Overall, students engaged in an authentic, partially, real-life context wherein they built and used a prototype vehicle that represented a "realistic analog" during the EDC.

\section{Data collection}

The study's primary data source included the five academic year coaching conversations the duo underwent. All coaching conversations were transcribed using modified Jefferson transcriptions conventions (Appendix 2). Nick also created a series of coaching log reflections, prior to and after each of the five academic year coaching conversations wherein he typed responses to planning or reflective-based questions, which are provided in Appendix 3. Finally, Nick generated field notes and collected classroom-based artifacts during Sammy's 9-day implementation (e.g. pictures), which were also referenced for contextual clues during data analysis and triangulation.

To begin the case study reported here I first organized the data sources listed in Table 1 into a case study database (Merriam, 2009) using a qualitative data analysis software program (Bazeley \& Jackson, 2013). Next, and with the aim of providing an "intensive, holistic description" (Merriam, 2009) of the case, I started analysis of the study's primary data: Sammy and Nick's Five Coaching Sessions. More specifically, the study's inductive analytical strategies started with the aim of constructing categories capable of interpreting the data collected, which in turn responded to the study's research questions. Ultimately, and as Merriam (2009) notes, data oftentimes "beg for continued analysis past the formation of categories" (p. 189); therefore, continued analysis occurred via the development of a working model that depicted the ways multiple categories operated. 
Table 1 Data collection timeline

\begin{tabular}{lll}
\hline Time Frame & Event & Data Collection \\
\hline June 2014 & Summer Curriculum Development & STEM-Integrated Curriculum \\
Sept. 2014 & Coaching Session \#1 ${ }^{\text {a }}$ & Transcribed Coaching Session (40 min) \\
Oct. 2014 & Curriculum Implementation & Field Notes - Classroom Artifacts \\
Nov. 2014 & Coaching Session \#2 & Transcribed Coaching Session (50 min) \\
Jan. 2015 & Coaching Session \#3 & Transcribed Coaching Session (60 min) \\
April 2015 & Coaching Session \#4 & Transcribed Coaching Session (45 min) \\
May 2015 & Coaching Session \#5 & Transcribed Coaching Session (90 min) \\
\hline
\end{tabular}

${ }^{\mathrm{a} A l l}$ coaching sessions include pre/post coaching log reflections

\section{Data analysis}

Constructed grounded theory (Charmaz, 2006) and Merriam's (2009) category construction guided all phases of data analysis. More precisely, during each stage of coding (initial, focused, and analytical) I developed codes intended to interpret and explain participant actions and processes. Given my familiarity with the context of the project and relationships with both participants, my analysis aimed to better understand both Sammy and Nick's "standpoints and situations" (Charmaz, 2006) in order to better explain their experiences together.

\section{Open coding}

Fully transcribed coaching sessions were initially open coded (Bazeley \& Jackson, 2013; Glaser \& Strauss, 1967) using phrases that reflect action (e.g. identifying an area for help). More precisely, incident-by-incident coding (Charmaz, 2006) was conducted while simultaneously listening to audio of, and reading transcriptions for each coaching session. Multiple codes could be applied to any given incident (typically three or less). In total, 600 instances were initially coded; approximately 400 of which were associated specifically with Sammy. In line with the study's overall design, transitions from one incident to another were determined by the researcher based on personal subjectivities and expertise derived via applicable past experiences (cf. McFadden, 2015). Incidents could therefore be as short as two speaking turns or last over $3 \mathrm{~min}$.

Additionally, two series of "selective codes" (c.f. Cohen, Manion, \& Morrison, 2007) were also applied to the aforementioned coaching session data. First, Laxton's (2016) dissertation research, which delineated influential "spheres of influence" that shape a coach's behavior when supporting teacher learning of reform-based instructional practice, were utilized. Of the spheres, the most frequently assigned code (35 incidents) related specifically to Nick's perceived role and responsibilities as a coach. Second, a series of selective codes derived from a project-provided coaching tool (Reflecting Forward/Planning Conversations; Appendix 1) were also selectively applied during open coding. This coaching tool (c.f. YorkBarr et al., 2006) contained potential questions (e.g. What haven't we considered yet?) and starter prompts Nick used to facilitate coaching conversations. By selectively coding for each "category" from the tool (a - getting started, b clarifying/reflecting, $c$ - reframing, $d$ - getting specific) I could identify Nick's most frequently employed coaching moves. In the end, application of each series of selective codes (spheres of influence: Laxton, 2016; and coaching moves: York-Barr et al., 2006) further supported my development of multiple, inductively-generated conceptual categories during the process of focused coding (Charmaz, 2006).

\section{Focused coding and category development}

With incident-by-incident coding completed, the entire data corpus could now be pieced together for fit and relevance while developing numerous conceptual categories during the process of focused coding (Charmaz, 2006). As Merriam and Tisdell (2015) note, each potential category is a "conceptual element" spanning as many incidents as possible. As focused coding continued, the criteria for assigning data to each category became more discriminate as categories merged, or diverged, given the researcher's interpretation of the data already categorized (Dey, 1993). From here, constant-comparative methods aided refinement of the data sources within each conceptual category as I began generating potential hypotheses capable of responding to the study's research questions (Glaser \& Strauss, 1967). Supplementary data sources were referenced and triangulated (Fielding \& Fielding, 1986; Patton, 2002) at this point as well, especially while creating analytical memos associated with a given conceptual category. For example, Nick's coaching log reflections helped me better understand his perspective after a coaching session if an already-coded incident from that specific session needed additional clarification.

Eventually a handful of conceptual categories emerged that contained representative and significant (previously disaggregated) data that can be found in Appendix 4). For example, multiple initial codes were conceptualized 
as pertaining to Sammy's prior customs/routines. Given the aim of focused and eventually analytical coding, my analysis searched for explanations of Sammy's behaviors so I also included contrasting incidents (Merriam, 2009) wherein she encountered pressures to change her customs and/or routines within the larger category because my theoretical framework aimed to investigate how teachers and coaches collaboratively undertook these "perceived pushes" for instructional change (Coburn, 2001). Ultimately, my inductive analytical strategies attempted to "crystallize participants' experience" (Glaser \& Strauss, 1967; p. 54) in order to provide an interpretive framework capable of making "relationships between implicit processes and structures visible" (ibid; p. 54). Upon completion of a final draft, Nick was provided with a "synopsis" document ( 2 pages) that detailed my interpretations of his individual experiences during data collection. After the member check no changes were suggested, though a few new insights were revealed (Merriam, 2009). ${ }^{2}$

\section{Results}

Four sections constitute the findings. To begin, data that reveal Sammy's suggestions for modifying the curriculum are presented, which also reveal her preferences for integrated instruction. Next, descriptions of Sammy's experiences with other coaches will follow; given these experiences highly shaped her expectations for Nick's support. Then, exchanges detailing precisely how Nick's coaching moves forced him into a precarious position with Sammy are presented. Finally, each participant's explanation for the misaligned expectations that resulted are revealed.

\section{Resolving the problems with their integrated unit}

Throughout their time together Sammy and Nick collectively attempted to identify opportunities wherein coaching support may have been warranted given implementation of the unit did not go that well. Due to her experiences with integrated curriculum, Sammy readily revealed that the issues associated with the unit that might be resolved by applying a few of her instructional preferences for integrated learning experiences.

To start, Sammy felt she needed to better understand the science content targeted in the unit, and when she implemented it this never quite happened. In the excerpt below, she described how immersing herself in the content during a different unit involving cameras and light had helped her gain conceptual confidence.

\footnotetext{
${ }^{2}$ Sammy elected not to participate in the member check upon being informed it was optional.
}

Sammy: after I know what works then I just literally spent like 2 days learning about cameras [Nick: $\mathrm{mhmm}$ ] and light [Nick: mhmm] just my: knowledge just took my: knowledge to the highest level because I mean if I teach K-5 I don't feel embarrassed that I didn't know a lot about topics that I never taught before [Nick: $\mathrm{mhm}$ ] and my science education that I received was weak in those areas [Coaching Session: May, 2015]

In order to gain much-needed confidence, Sammy unapologetically stated here she would deepen her own knowledge when necessary if she knew what to focus on. During the unit her and Nick codeveloped, she felt unsure regarding the content. She later described it as "confusing" because she was unfamiliar with hovercrafts, a vehicle utilized during the EDC.

Sammy: to know (the content) at the highest level, I know camera obscuras more than a lot of other people that know it at a basic knowledge $\uparrow$ [Nick: $\mathrm{mhm} \mathrm{mhm}]$ I feel like I had $\downarrow$ but to go to a hovercraft and to learn specifically about hover crafts, I'll have to do that if I know that/ that's gonna work with the kids, ( ... ) so I'm like I'll go and research about hovercrafts in particular but like for me to feel confident

Nick: okay so that's not really the content knowledge [that's more]

Sammy: [for me it is]

Nick: okay [Coaching Session: May, 2015]

After Nick stated that the scientific content embedded in the unit did not necessarily consist of just "hovercrafts", Sammy posited the conceptual ideas inherent within the design and operation of a hovercraft were equally as important as the concepts necessary to understand the vehicle's motion. The month prior, she explained that when her "insecurities" were exposed, student behavior became an issue and during the unit this had occurred due to the materials.

Sammy: so when we were doing the force diagrams (in class) IF I felt really comfortable like drawing it instantly, that would have been better/ if you had asked me to diagram the light rays in the camera I can do that and that gives me confidence (as opposed to when) the kids are sensing that I'm insecure with it and they're going to respond to that by acting out because they wanna feel safe and confident in their teacher because they're going to show me (otherwise if) they don't [Coaching Session: April, 2015] 
As she noted later in the year, Sammy "never had another unit where (she) couldn't fix it, where she couldn't address the content knowledge (issue)" (Coaching Session: May, 2015). When multiple problems with the unit emerged, her self-confidence was negatively impacted causing her to question if hovercrafts were an appropriate addition to her curriculum given they were unfamiliar to her and her students. As a result of this mishap and a few others, Sammy soon determined the problems associated with the unit might be revolved if more of her instructional preferences and routines were incorporated into it.

\section{Sammy's routines for STEM integration}

Sammy frequently told Nick she knew of certain strategies she had used before that had helped her implement other integrated units. In the current unit however, many of these routines were missing.

Sammy: before I teach it again I need to figure out how to keep as many of my routines as I can and still achieve the goals of our unit ${ }^{\circ}{ }^{\circ}$ I think a lot of it is bringing the math in (.) when I had them last year for science I wasn't doing the math [Coaching Session: November, 2014]

Nick, having picked up on a cue to focus a bit on mathematics integration here, later asked Sammy to describe why changing a lesson dealing with force and change of motion might be justified. More specifically, he wanted Sammy to reflect on the decision to eliminate this lesson; given it tasked students with analyzing a data set using roto-planes while providing much needed experience using propellers, which both served as preparatory experiences for students before the EDC. As described later on, Sammy felt that eliminating the less familiar lesson involving roto-planes was necessary because she had a similar lesson that tasked students with rolling spheres down a ramp. This more familiar lesson also required students to analyze a graph after generating a subsequent data set; though it required analysis of a line graph and not a scatterplot as originally intended, which may have been less applicable to the EDC.

As in the above example, Sammy often revealed a preference for familiar lessons like this that better followed her routines. She believed that even though she wanted to make these adjustments she could still "achieve the same goals" [Coaching Session: November, 2014]. Below, she described an adjustment that needed to be made after attempting to address multiple "learning targets" during a single lesson.
Sammy: I went back to how I taught before the project and for my teaching/ and it might be something I can grow towards: like I'm used to one learning target so like when a lab targeted more than one/ or when I was trying to do the graphing from the day before and then start a lab it was like if my brain's not handling it, the kids (are) not handling it, they're used to one learning target (.) we're all trained, we gotta have a guided question and a learning target and I think it was just too big a change, we gotta keep our routines and what's going strong [Coaching Session: January, 2015]

Nick followed Sammy's response here, asking if "we" had encouraged her to display multiple learning targets. She replied "no", stating that time was a "restricting" factor. Sammy did indicate here she "might" be able to "grow" (i.e. more than one target); however, her prior preferences and school customs were still highly influential regarding any changes to the unit.

Elsewhere, Sammy brought up that she had struggled to help students make daily connections to the unit's overarching context (i.e. designing a rescue vehicle) because they were learning various motionrelated concepts using different vehicles day-to-day. As a result, she had to give lots of verbal, step-bystep "directions" that students struggled to follow or really care much about, as they instead had "toys" they could "play" with.

Sammy: so they're engaged and they're actually able to comprehend (what's happening) as we're talking and it's not like a list of directions, (and then) I'm not having the behavior interruptions when I'm talking $\uparrow$ [Coaching Session: April, 2015]

Sammy openly admitted here and elsewhere that numerous "behavior" issues arose when Nick was present. And while she later attributed some of this to an "observer effect" [Coaching Session: May, 2015], she also expressed frustration because obstacles like this hardly occurred when she followed her tried-and-tested routines. When her students failed to keep track of the unit's primary contextual driver because too many vehicles (i.e. materials) were being used to teach various scientific concepts, she decided to address this issue by again following a more familiar strategy.

\section{Material issues}

The materials associated with the unit were somewhat complex, meaning they repeatedly proved problematic for Sammy's students. Nick undoubtedly knew coaches commonly help teachers with "materials-based challenges" (cf. Campbell \& Malkus, 2011) and as will be 
seen later he asked Sammy multiple questions related to this hoping she might discover solutions to this challenge. Sammy eventually decided that utilizing a single vehicle or "technology" would be best as this strategy had worked for her in the past.

Sammy: if I had given them a basic vehicle and had them do the friction (test) (.) do you know/ have them do (the) ex=experiments, have them go from ramps with it, have that to start it right away with the base vehicle=that=hooks=some of them in and then it just/ I wasn't good at connecting the lessons as much as I could (have) (.) for me it's easier to work with the same invention or technology the whole time so that might have just been an accommodation for me and that might be why the cameras are working better [Coaching Session: April, 2015]

As yet to be revealed, Nick more often than not elected to withhold his expertise when changes to the unit were up for debate. Nick did prompt Sammy to reflect on her idea if narrowing the contextual scenario was necessary (e.g. "why do you think you haven't had a whole lot of success with ..." ); though his efforts did little to convince Sammy the unit could still be successful without making major changes. Nick perhaps felt that Sammy's idea to utilize a common, "basic" vehicle might limit opportunities for students to transfer knowledge related to the motion of objects between varying contexts (cf. Schauble, Klopfer, \& Raghavan, 1991); though this concern was not discussed.

Regardless, Sammy felt students could be provided with a list of directions to follow as they assembled their vehicle; noting this "accommodation" would enable her students to have a "foundation of success" and specific "entry points" into the unit's context. After Nick asked her to elaborate more on her justification for utilizing a single vehicle, Sammy stated students in her class this year had been "tougher" than usual.

Sammy: so: I'm just saying this is a tougher class (of students) like not just with me but in general like it is a tougher class: so I'm saying that's an accommodation that's worked $\downarrow$ for me (.) so [Nick: ok] but I'm not saying the fire rescue vehicle wouldn't work for other teachers $\uparrow$ that's how I'd accommodate it for me [Coaching Session: April, 2015]

Stated differently, Sammy later told Nick she needed to take "down the level of difficulty" in the unit because its "openness" created unnecessary challenges (Coaching Session: April, 2015). Nick responded by asking Sammy if her students' "lack of knowledge with physics" had "inhibited their ability to be successful" during the EDC (Coaching Session: April, 2015). Sammy responded, claiming her students were usually stronger in "biology" and "not physics" because they last experienced physics content in the first grade. Eventually, Nick's attempt to spur reflection on the merit of this decision ended as Sammy pressed forward stating the lessons she implemented just needed to be "stronger".

As evidenced above, in order for Sammy to successfully implement the unit again (a) student behavior needed to a non-issue, (b) she needed feel confident in the scientific content being targeted, and (c) she needed to more clearly connect the unit's context and sequencing of lessons by limiting the material choices students were exposed to.

\section{Reflecting for change}

Nick recognized a cognitive "breach" (Weick et al., 2005) resulted after Sammy's implementation, which had likely caused her to suggest these major changes to the unit. As partially evidenced above, Nick's reflective-based coaching moves did little to convince Sammy an instructional "model that's worked for (her)" [Coaching Session: May, 2015] might need to be adjusted. Instead, she believed the unit needed to better match her preferences and routines. Of note, Nick also mentioned Sammy talked "rather quickly" and this made it difficult for him to "focus their conversations" [Pre-Coaching Log (Nick): January, 2015]; a predicament he later expounded upon within a written reflection.

I tried several times to press her for evidence of some of the things she was observing, and I think this did help her to reflect more deeply on what was happening. That being said, Sammy is naturally reflective and extremely self-critical. The hard part for me, and what I spent most of my time focusing on was, is trying to focus that reflection and selfcriticism in productive ways. [Post-Coaching Log (Nick): April, 2015]

As will be revealed, Sammy never fully understood the nature of Nick's coaching support and Nick never felt his coaching role permitted him to exhibit his own expertise and intervene when Sammy proposed ways in which to modify the curriculum. As Nick pointed out here, he therefore found it difficult to lead "productive" coaching sessions with Sammy. As described in the next section, Sammy became frustrated with the outcomes of their coaching sessions because her prior experiences with coaches had been very different. 


\section{Sammy's expectations for being coached}

Sammy's previous coaches were instituted due to the district's low scores on the state's standardized science assessment, a fact Sammy told Nick during their first meeting. The exact model these school-based coaches employed with Sammy is not fully known; though based on her descriptions of their support, it varied quite noticeably from Nick's approach. For example, Sammy initially anticipated Nick might help her resolve some of the problems associated with the unit given they had developed it together - an idea she discussed early on while describing how she had worked with two previous coaches.

Sammy: she's [previous coach] a science (person) and she she's just very enthusiastic (.) she has suggestions, she also has the enthusiasm that goes with it $\uparrow$ so that was really good (.) um the past two years: um: with Mr. King it's been (.) we have a different style of communication so it's still helpful and in a way he's helped me the most because he pushes you which is good but I kind of I tend to gravitate towards coaches where you can think of ideas together $\uparrow$ so I think it's awesome that I've actually had two very different coaches. Mr. King's is more like a psychiatrist like what do you think ((laughter)) but (he) does make you reflect [Coaching Session: September, 2014]

As Sammy noted here, both coaches typically provided her with "suggestions" and/or "ideas". Elsewhere Sammy likened her experiences with the "enthusiastic" coach as having a "co-author on a book". She later clarified how her and Mr. King worked together, noting that in the past he had also offered her direct suggestions to implement.

Sammy: Mr. King would say something like okay, (I know) you've been coached this way, but for science this is how we do it (.) so I was like, for this year I got rid of my circle (time) for fifth grade and fourth grade cause he's like that's not working for science, you need to get them right into the content=and we can't/we don't have those minutes for circle (.) so that was very helpful. [Coaching Session: September, 2014]

Sammy expressed nothing but praise for Mr. King and his coaching support, also telling Nick at one point she "trusted his opinion". In general, Sammy appreciated any and all advice she might receive and she especially pronounced an appreciation for Mr. King's support because he offered her specific improvements and actionable feedback. She also noted her capacity to handle "contradictory" coaching advice, thereby indicating a level of self-confidence she could make decisions upon receiving varying advice.

Sammy's expectations for Nick and his coaching support were highly influenced by her experiences working with other coaches in her school. As the prior section suggested (and the next more fully describes), Nick's support failed to match these expectations as he maintained his reflective-based "roots"; mostly prompting Sammy to reflect on her instructional decisions prior to and after implementing the unit. The following section depicts how Nick's coaching moves positioned him in a manner Sammy ultimately found quite unhelpful.

\section{How Nick positioned himself as a coach}

Nick repeatedly communicated to Sammy that she held decisional ownership regarding potential changes to the curriculum because implementing it involved "her classroom, her kids, and her lessons" [Coaching Session: May, 2015]. During earlier sessions Nick stated Sammy would not be "pushed" in any particular direction, as his opinions were coming from an "outsider" [Coaching Session: November, 2014]. In the excerpt below, he explained that his prior experiences in the classroom were not necessarily at the elementary level.

Nick: we hopefully won't have that problem too much with me because uh you know my background is uh not necessarily in um elementary science or I mean/ I taught science but I'm not saying elementary science so um so: yeah, I won't be/I'm not trying to push you in any one way or the other [Coaching Session: September, 2014]

As Nick pointed out here, he did not want to offer advice that countered Sammy's own preferences, believing that letting her know this might prevent "problems". Instead, he wanted his coaching support to empower Sammy and better her practice by helping her become more reflective. In order to accomplish this, he leveraged his expertise to ask relevant and purposeful questions; and not necessarily offer up his opinions which countered Sammy's expectations for his support. For example, Sammy asked Nick what he thought about eliminating a mathematics lesson from the unit, shortly after implementation.

Nick: yeah okay that's okay I I I think that I think that I think so in trying to decide what to cut though/ you're (.) the things that are important to you as far as the activities you choose (.) [Coaching Session: November, 2014] 
Prior to Nick's statement, Sammy hesitantly stated that she felt requiring students to take the additional step of organizing and interpreting multiple data points might be unnecessary and students could instead interpret the line graphs they generated via their own, smaller data sets. Nick responded by stating it would only be possible for students to interpret scatterplots and explore potential "trends" if they generated larger sets. After hearing Nick explain the similarities and differences between creating/interpreting a line graph and a scatterplot, Sammy decided not to "take it up a level" [Coaching Session: November, 2014] because as she had discovered earlier her students had not been prepared to interpret a scatterplot. As similar situations like this arose, Nick continued to withhold his opinion, which unequivocally meant Sammy was charged with modifying the unit and making these decisions herself - unsurprisingly these changes gravitated significantly towards her prior instructional preferences.

On one occasion, Sammy's process for retrofitting the unit in this manner took an unexpected turn, as she discovered Nick had withheld reservations concerning the use of a certain vehicle because it had a rechargeable battery. In the next exchange, Nick revealed he had done this because of his "strange role".

Nick: you were really excited about the idea (.) about the battery/that the power source had to be rechargeable/and I was concerned about that and I probably should have said something earlier but I uh you know it's/I mean I'm a part of the team but I also, I have like a strange role and [Sammy: yeah that's true/yeah] we're still trying to figure out the way (.) as to how much I can contribute [Coaching Session: May, 2015]

Nick's level of contribution to the pair's joint endeavor always seemed to be in question as he eluded to here. This proved especially problematic at times given they needed to resolve overtly challenging issues. In order to illustrate the difficulty of one challenge they encountered, the next exchange exemplifies how the integrated nature of the unit and requirement to incorporate various materials created complex dilemmas that needed to be addressed.

Nick: you said you felt like the roto planes went a little bit better um (.) and the uh the rolling spheres/how did that apply/how did that [prior science-based lessons] apply to the (students' efforts when engaged in) engineering design? [Sammy: $\mathrm{mhm}$ ] did you see them using what they learned $\uparrow$ (during these lessons) in their (final) designs

[Coaching Session: January, 2015]

Sammy responded to Nick's prompt here with an unemphatic "yup", along with her justification for eliminating the balloons as an option for students to power their vehicles. She then explained students could use propellers instead, thereby "applying" what they learned about "directionality of force" from the roto-planes experiment as they designed their rescue vehicles. Given her response, it is unclear if Sammy recognized the importance of providing opportunities for students to demonstrate knowledge application in varying contexts, which Nick may have been alluding to here (cf. Brophy, Klein, Portsmore, \& Rogers, 2008; Schauble et al., 1991). Regardless, this exchange highlighted how Sammy had been positioned as an expert via Nick's coaching moves, which was inevitably different for her and at times frustrating due to the complex nature of the challenges that needed to be addressed.

During their final coaching session Nick explicitly called out his reluctance to provide direct suggestions for Sammy. In the exchange below, Sammy had been trying to determine a way to measure the reflection angles of a camera during an upcoming lesson.

Nick: I think that we need to stop um because we're talking in circles a little bit now, okay I do want to say uh as far as the angles go on this (camera) I have a suggestion [Sammy: okay] and I'm just going to give it to you/I've been reluctant to give you suggestions all year but I'm going to do it Sammy: but if you don't feel like that's your role I can go ask Mr. King

Nick: no that's okay because I feel like I can be helpful [Coaching Session: May, 2015]

Sammy quickly realized Nick's support had changed here as he went on to suggest a plausible solution for the problem at hand; a coaching move he had been "reluctant" to use throughout the year because he believed his coaching role had limited him from doing so. When asked about his decision to default to Sammy's expertise during the member-check, Nick stated he felt his own credibility with Sammy was always in question because he had never been an elementary teacher. And while he trusted his own expertise, he believed it would be "offputting" to frequently assert it because "more barriers", than bridges would be constructed. Nick also instituted this same mindset concerning Sammy's instructional practice, stating he could be a "second set of eyes" in the classroom for her and afterwards he would help her 
"articulate" the effectiveness of the lesson (Coaching Session: September, 2014); which again varied from Sammy's prior coaches who openly critiqued her practice and provided direct suggestions for improvement, sometimes during the actual lesson.

\section{Hesitant to critique instruction}

Counter to Sammy's prior coaches, Nick found it somewhat stressful to provide feedback for Sammy as she struggled on occasion in the classroom (cf. Mangin \& Dunsmore, 2015). He also believed Sammy realized he held back certain criticisms; stating his attempts to hide his feelings may have not been "entirely successful" [Post-Coaching Log (Nick): April, 2015]. He privately commented on Sammy's instruction elsewhere, noting she "worked very hard to maintain order and control even at the slightest outburst" in a coaching log [PostCoaching Log (Nick): April, 2015]. He also felt that using this energy to maintain order had taken "away from (Sammy's) ability to address what students needed in terms of content" [Post-Coaching Log (Nick): April, 2015]. Within his final reflection, he stated this "big issue" concerning classroom management would likely never be discussed with Sammy, which made it "hard (for him) to focus on what she wanted to talk about" [Post-Coaching Log (Nick): April, 2015]. This issue arose because he never figured out how to address it with Sammy, let alone resolve it. Of note, he had once suggested they watch a video of Sammy leading a classroom discussion together (a strategy he learned about in his coaching class), though she detested this idea claiming she wanted to "move past" her implementation [Coaching Session: April, 2015]. During their final session together, Nick commented on his stance regarding Sammy's instruction; explaining he had reserved his support within the bounds of the coaching model being employed.

Nick: I try to just go by the feedback that seems to be helpful right and (.) um (.) so when, during the unit I could sense that you were struggling but I/ you know it's not my place to step in and tell you how to do things so I didn't exactly know what you needed [Coaching Session: May, 2015]

He went on to explain he might have needed to be "more direct" concerning potential changes to the unit and her instruction; however, he also stated he felt Sammy had been "asking him for ideas" and this was "not his place". The month prior, he disclosed a similar notion writing that he got the "impression" Sammy wanted him to "fix things" and provide more "concrete solutions" [Pre-Coaching Log (Nick): April, 2015].
While working with Sammy, Nick found himself in a mystifying situation due to the study's larger context. Concisely stated, a specific coaching model had been selected for Nick to "follow" because when the project ended, coaches and their support would be dissolved. The coaching model Nick enacted therefore intended to empower Sammy; not enable her to be reliant on outside, soon-to-be unavailable support. In essence, the reflective-based support being offered had intended to help Sammy propose and reveal the outcome (positive or negative) of the solutions she wanted to pursue (Costa \& Garmston, 1994). As evidenced above, unanticipated and disparaging results emerged as one individual continuously needed to interpret the true nature and value of the other's support; while the other felt contrived to offer up supports that came across as veiled and likely disingenuous.

\section{Attempting to explicate the cause of misaligned expectations}

During their final coaching session, both parties tried to express to one another the causes for the challenges that had resulted. As detailed above, Sammy felt she had provided solutions to resolve certain challenges that arose after her implementation - provided any potential change lined up with one of her prior preferences for integrated instruction. Unfortunately, the supports being offered by Nick to aid in these translation efforts failed to match Sammy's expectations; despite having been informed about the nature of Nick's coaching support when they first met (i.e. reflective-based, blended coaching model). Given her prior experiences with coaches, Sammy became confused and frustrated as Nick's support was deemed restricted and not at all like her experiences with prior coaches. In the end, Nick never felt comfortable interfering with Sammy's process for improving the unit (and his coaching moves did little to alter this process); later stating he felt Sammy simply wanted him to fix many of the problems associated with the unit. Sammy however, claimed that her preparation "style" and Nick's never matched.

Sammy: for some reason when (I've been coached before), her style just matches mine [Nick: $\mathrm{mhm}$ ] and I've had like (.) she's super/ like her style of preparing is like mine and I don't feel nervous and I just act myself [Nick: mhm] so I meet with her and she's like that was awesome ${ }^{\circ}{ }^{\circ} \downarrow$ and I meet with you and it's like THIS (.) I don't know. I just didn't feel PREPARED I guess so my confidence was down $^{\circ} \downarrow \downarrow$ [Coaching Session: May, 2015]

After Sammy revealed the potential cause for her feelings of frustration, Nick followed up, attempting to 
explain why his supports were potentially unhelpful and perhaps inconceivable given the expectations for support Sammy insisted would have "helped her".

Nick: my goal as a coach was to help you reflect/like my goal my my my my my goal as a coach was not to come in here and say do this or don't do that/here's how you could improve this unit right [Sammy: oh $\uparrow$ ] my goal uh my role as a coach/I never taught fifth grade right (.) I've taught high school physics so um (...) um ( ... ) so w/part of the project is to rely on YOUR expertise with your classroom and then to work with the project to integrate STEM [Sammy: oh:] at a higher level right [Coaching Session: May, 2015]

Nick wanted to communicate the juxtaposition and precariousness of being positioned between his predetermined role for being Sammy's coach and Sammy's expectations for his support. He clearly never intended for Sammy to be impacted in this manner, but unfortunately his support left her quite bewildered. The study's findings illustrate Nick's attempt to reconcile this taxing dilemma and ultimately its impacts on both his coaching moves and Sammy's desire for more involved support given the challenges that had arose.

\section{Discussion}

The tensions that resulted when Nick felt pressured to confine his supports for Sammy stemmed from the belief he needed to strictly maintain the project's reflective-based coaching model (Lord et al., 2008; Mangin \& Dunsmore, 2015). Sammy struggled to understand the nature of Nick's support and during their final meeting each participant's reasoning for the frustrations that emerged were divulged. Ideally, these frustrations would not have resulted; however, a transitional structure associated with the project (transitioning from coaching support during the development of the curriculum to classroom-based coaching focused on curriculum revisions; McFadden \& Roehrig, 2017) may have contributed to this outcome. Briefly stated, the focus of Nick's support had switched - potentially meaning expectations should have been discussed and readjusted. Prior to exposing these tensions, Nick's efforts to mask or conceal his true concerns were thwarted, as he wavered to offer plausible supports for Sammy who ultimately found the whole situation quite perplexing. Prior to their final session, trust issues also intervened as neither felt entirely comfortable openly discussing their ideas with one another (Anderson et al., 2014); thereby preventing much needed dialogue from occurring as veiled conversations ensued (Chia, 2000).

Initially, Sammy anticipated Nick's expertise would be quite helpful given they adapted the curriculum together (cf. Mudzimiri et al., 2014). The possibility remains she would have benefited from more direct coaching supports (cf. Deussen, et al., 2007; Ippolito, 2010); similar to her prior experiences with coaches like Mr. King. Upon analysis, Nick's decision to withhold expertise regarding both the curriculum, as well as critiques regarding Sammy's implementation could be viewed as problematic (cf. Gibbons et al., 2017), yet theoretically defensible given he ultimately believed Sammy would benefit from more "self-directed learning" (Costa \& Garmston, 1994), which he had strived to facilitate. For the most part, Nick vehemently upheld his reflective-based coaching role, perhaps to an extreme, hoping the "productive struggle" that resulted would eventually be beneficial in the long term. For Sammy, the struggles and subsequent crisis that resulted had positioned her to seek out direct, "external assistance" (Costa \& Garmston, 1994). Given Nick had co-developed the curriculum with her (and due to her prior coaching experiences), Sammy had anticipated more involved support to help her overcome the limitless problems that had emerged with the integrated unit she implemented.

\section{Reciprocal learning}

During the member-check Nick stated he felt he could never "prove" his own credibility to Sammy because he had never been an elementary teacher and this impacted his perceptions of their relationship and capacity to support Sammy. Bengo (2013) has reported a similar finding; claiming secondary science teachers preferred coaches that could "prove" a certain level of subject matter expertise. Had Nick been able to deviate from his strict coaching role (Gallucci et al., 2010) and more freely provide his ideas and opinions for Sammy to contemplate (similar to the coach she identified as her "coauthor"), he could have conceivably built up his own credibility as Sammy listened to his ideas and perspective. This would have simultaneously presented opportunities for Nick to better understand and learn from Sammy and her experiences in the classroom (i.e. reciprocal learning; Knight, 2007), given she recurrently presented concerns Nick believed were seemingly trivial; concerns for Sammy that were grounded in her decadelong experience as an elementary teacher. Tensions understandably emerged here as expectations were misunderstood and much needed dialogue lapsed, leaving Sammy frustrated she had been positioned as the expert and Nick maintaining a stance he needed to withhold expertise and much desired feedback (Mangin \& Dunsmore, 2015). When viewed holistically, limited opportunities 
were provided for Sammy to make connections between her current model for integrated instruction and potentially new instructional strategies (Weick et al., 2005); a potentially key outcome of reflective-based coaching (Lord et al., 2008).

\section{Conclusions: implications and future research}

Provided the integrated curriculum Sammy implemented had just been developed (making this its initial debut), the focus of the pair's coaching conversations might have focused more on the effectiveness of individual lessons using applicable evidence sources (i.e. student work and/or responses; Knight, 2007). Unfortunately, coaching sessions were extended well after her implementation of the curriculum and the focus of their conversations inevitably began to deviate more towards Sammy's everyday instruction (as intended via the study's larger context and aims). This became problematic however, as a much-needed cycle of pre-planning, execution, and reflection failed to emerge. Future projects involving both curriculum development and coaching support might consider how a coach's role needs to transition as the supports that are needed fluctuate with varying circumstances and expectations.

The tensions that resulted due to the pair's misaligned expectations represents one of the study's primary finding; a finding that should incite a need for future research. Specifically, more strategic planning for teachers and coaches may be warranted prior to sending pairs off to work for extended periods of time. Simple strategies worth instituting and exploring would involve collecting information regarding a teacher's past coaching experience. If teachers were to identify useful or problematic supports they had previously received, discussions that aim to reveal the expectations for forthcoming (i.e. potentially "new") support might occur early on with leadership or potential coaches to hopefully assure proper alignment between what can be provided and what may be sought or desired. As highlighted in the current study (and as advocated for recently), a need persists to investigate how multiple teachers might respond to differentiated coaching support. Jacobs et al. (2018) have proposed that appropriately involving teachers in decisions regarding potential instructional supports may improve their "sense of agency" (e.g. identifying a preference to work with a former elementary teacher or a content expert). The findings reported here provide a case study example that portrays how assuming any coach can work with any teacher may lead to unfortunate circumstances.

Given recent calls to teach science and/or integrated STEM across each and every grade level
(Banilower et al., 2013), similar situations wherein misaligned expectations negatively impact teacher support may arise because elementary teachers are paired with coaches whom have only taught middle or high school (Coburn \& Woulfin, 2012). Conceivably, the time may be approaching for coaching qualifications in science and/or STEM to be further explored as has been done in other disciplines (e.g. International Reading Association, 2004). Additionally, there may be a need for coaches paired with elementary teachers to embrace more concrete instructional support (e.g. co-teaching and modeling), provided teachers self-identify a lack of experience and/or familiarity with content integration across disciplines (Gibbons \& Cobb 2017; Woulfin \& Rigby 2017). Making the decision to adjust coaching supports in this manner would obviously impact a coach's role and examinations of such adjustments may provide fertile grounds for innovative coaching models and/or frameworks to emerge, specifically related to science and/or STEM integration at the elementary level.

\section{Limitations}

The current study contains certain limitations given it consisted of a single teacher paired with a single coach. The findings presented should therefore not be viewed as generalizable, but rather as a response to calls in the literature for more in-depth, qualitive inquiries that examine teacher-coaching partnerships (Desimone \& Pak, 2017; Jacobs et al., 2018). Analysis of the data presented did answer the study's single research question by exhibiting the unforeseen outcomes of executing reflective-based coaching support with an elementary teacher during implementation of an integrated unit; though only by examining a single case. Nick's support was non-supervisory, meaning he needed to leverage personal expertise and relationship building as primary drivers for supporting Sammy (Gallucci et al., 2010). Ultimately, this process was more difficult to accomplish than initially conceived and the possibility remains that different coaches may have responded differently when pressed to adjust their roles as Nick had been (Lord et al., 2008). Additionally, contextual challenges may have constrained Nick's support as he transitioned from supporting development of the curriculum in the summer to supporting instruction and curriculum adaptation during the school-year (Note: tensions related to potentially publishing the curriculum may have also created some tensions for Nick and/or Sammy, though it was never explicitly mentioned). Finally, Sammy's implementation occurred extremely early in the school year (see Table 1), which perhaps left the duo too much time afterwards to discuss revision of the curriculum during their required monthly coaching sessions. 


\section{Appendix 1}

Table 2 Reflecting forward/planning conversations

\section{a) Getting Started}

- Tell me about what you're working on

-What are some of your overarching goals with this unit?

-What questions are you considering?

-What would you like to see happen?

-What are you most excited about?

- What do you expect students will already know and be able to do?

-What are some ways you can move this forward?

-What will success look or feel like?

-What will be some indicators that you are making progress?

\section{b) Clarifying/Reflecting}

- So you're thinking that ...

- You're wondering if ...

- You're concerned about ...

- So there are three issues here ...

- On the one hand ... and on the other hand ...

- It's important to you that ...

- An assumption you're operating from is ...

- An example of what you're talking about could be ...

\section{c) Re-Framing}

-What are some other ways of thinking about this?

- Has this always been the case, or have there been times where things have been different?

-What haven't we considered yet?

-Who else might we talk to about this idea?

- What are your reasons for doing things this way? How might the outcome change if we did things a different way?

-What are some alternative possibilities you haven't considered yet?

- Are there other resources we should take a look at?

\section{d) Getting Specific}

- Which of the 2-3 ideas that you've mentioned would you like to try?

-What data could you collect to measure your success?

- How will you know what the students have learned?

-What resources will you and students need to do this?

-What will each group member need to contribute to move ahead?

- Does what you are considering help students to meet the standards?

- Where are we right now in the curriculum design process? Where do we go next?

\section{Appendix 2}

Table 3 Transcription conventions ${ }^{a}$

\begin{tabular}{|c|c|c|}
\hline Definition & Code & Example \\
\hline Descriptive text & $(())$ & ((Laughter)) \\
\hline Accompanying text & () & $\begin{array}{l}\text { they learned } \\
\text { (during these } \\
\text { lessons) in }\end{array}$ \\
\hline \multirow[t]{2}{*}{ Overlapping speech } & ] & A: [ \\
\hline & & B: [ \\
\hline Increased volume & UPPERCASE & \\
\hline Decreased volume & $\circ \circ$ & \\
\hline Latched or continuous speech & $=$ & \\
\hline Stretching of sound & : & \\
\hline Short pause & (..) & \\
\hline Longer pause & $(\ldots)$ & \\
\hline Dropped or interrupted utterance & / & \\
\hline Falling intonation & $\downarrow$ & \\
\hline Rising intonation & $\uparrow$ & \\
\hline
\end{tabular}

${ }^{a}$ Transcription conventions are adapted from the Jefferson system. The format of the conventions table is modeled on one used in Majors (2007)

\section{Appendix 3}

Table 4 Coaching log reflective prompt

\section{Pre-Coaching Session}

What will be the purpose of the meeting?

Describe your goals for this session. What do you hope the teacher will get out of this meeting? What do you hope to get out of this meeting?

What are the teacher's current goals for their STEM integration efforts?

What concerns or challenges do you anticipate going into this meeting?

Describe, in detail, your plan for the upcoming meeting, including questions you plan to ask, protocols or other coaching resources you will use, and other plans you have to facilitate this teacher's learning.

\section{Pre-Coaching Session}

What was the purpose of the meeting?

In 5-7 sentences, summarize the focus of the meeting.

What was the key learning for you and the teacher?

What do you want to remember for next time?

Describe the coaching decisions you made. Why did you make these choices?

What worked or didn't work? What are some possible reasons for why things went the way they did?

What will be your next steps in supporting this teacher's learning? 


\section{Appendix 4}

Table 5 Conceptual Categories Generated via Focused Coding

\begin{tabular}{|c|c|c|}
\hline Category Name & Brief Description & Instrumental Initial Codes ${ }^{a}$ \\
\hline $\begin{array}{l}\text { Sammy: Changes } \\
\text { vs. Customs }\end{array}$ & $\begin{array}{l}\text { Expressed preferences for Sammy along with identified, potential changes that } \\
\text { might threaten her instructional preferences. }\end{array}$ & $\begin{array}{l}\text { coaching customs, being accustomed to, } \\
\text { project-related pressures for change }\end{array}$ \\
\hline $\begin{array}{l}\text { Sammy: Thinking } \\
\text { About Students }\end{array}$ & $\begin{array}{l}\text { Bringing students into the discussion and considering how they impact } \\
\text { teaching and learning STEM. }\end{array}$ & $\begin{array}{l}\text { engagement creates possibility, the negatives } \\
\text { of being open-ended }\end{array}$ \\
\hline Sammy: STEM & $\begin{array}{l}\text { Talking about what STEM is to her and how it impacts her instruction and } \\
\text { students. }\end{array}$ & making it work, students in STEM \\
\hline $\begin{array}{l}\text { Sammy: Resources } \\
\text { for STEM }\end{array}$ & Planning for and considering logistical aspects associated with STEM instruction. & planning for action, worrying about materials \\
\hline $\begin{array}{l}\text { Sammy: Being } \\
\text { Proactive }\end{array}$ & $\begin{array}{l}\text { Sammy's willingness to enact change and improve her instruction and student } \\
\text { learning in STEM. }\end{array}$ & $\begin{array}{l}\text { identifying an area for help, what had to } \\
\text { happen, reaching out to peers }\end{array}$ \\
\hline $\begin{array}{l}\text { Nick: Role } \\
\text { Confusion }\end{array}$ & $\begin{array}{l}\text { Nick's uncertainty concerning his role with Sammy. Behaviors that wavered } \\
\text { between directly helping her or simply withholding expertise. }\end{array}$ & $\begin{array}{l}\text { who has the expertise, providing an opinion, } \\
\text { empathizing, letting Sammy decide }\end{array}$ \\
\hline $\begin{array}{l}\text { Nick: Commenting } \\
\text { on Instruction }\end{array}$ & $\begin{array}{l}\text { Nick's actions and behaviors that directly or implicitly indicated to Sammy she } \\
\text { needed to make instructional changes. }\end{array}$ & $\begin{array}{l}\text { identifying expertise, apologizing, Sammy's } \\
\text { deficits }\end{array}$ \\
\hline
\end{tabular}

${ }^{\mathrm{a}}$ Only select initial codes are listed here

\section{Abbreviations}

STEM: Science, technology, engineering, and mathematics; EDC: Engineering design challenge

\section{Acknowledgements}

Not Applicable.

\section{Authors' contributions}

GR and JM co-designed the study. JM collected the data and carried out the analysis. JM drafted the manuscript. Both authors read and approved the final manuscript.

\section{Funding}

National Science Foundation, Division of Elementary, Secondary, and Informal Education (\#1238140)

\section{Availability of data and materials}

The datasets used and analyzed during the current study are available from the corresponding author on reasonable request.

\section{Competing interests}

The authors declare that they have no competing interests.

\section{Author details}

${ }^{1}$ College of Education and Human Development, University of Louisville, 1905 South 1st Street, Louisville, KY 40292, USA. 'Learning and Environmental Science 320, University of Minnesota, 1954 Buford Ave, St. Paul, MN 55108, USA.

Received: 14 October 2019 Accepted: 11 March 2020

Published online: 27 March 2020

\section{References}

Anderson, C. W., de los Santos, E. X., Bodbyl, S., Covitt, B. A., Edwards, K. D., Hancock, J. B., ... Welch, M. M. (2018). Designing educational systems to support enactment of the next generation science standards. Journal of Research in Science Teaching. https://doi.org/10.1002/tea.21484.

Anderson, R., Feldman, S., \& Minstrell, J. (2014). Understanding relationship: Maximizing the effects of science coaching. Education Policy Analysis Archives, 22(54), 1-16 https://doi.org/10.14507/epaa.v22n54.2014.

Banilower, E. R., Smith, P. S., Weiss, I. R., Malzahn, K. A., Campbell, K. M., \& Weis, A. M. (2013). Report of the 2012 National Survey of Science and Mathematics Education. Horizon Research, Inc. (NJ1).

Banilower, E. R, Smith, P. S, Malzahn, K. A, Plumley, C. L, Gordon, E. M, \& Hayes, M. L. (2018). Report of the 2018 NSSME+. Chapel Hill: Horizon Research, Inc.
Bazeley, P., \& Jackson, K. (2013). Qualitative data analysis with NVivo. London: Sage Publications Limited.

Bengo, P. (2013). Mathematics coaching to improve teaching practice: The experiences of mathematics teachers and coaches (doctoral dissertation).

Brophy, S., Klein, S., Portsmore, M., \& Rogers, C. (2008). Advancing engineering education in P-12 classrooms. Journal of Engineering Education, 97(3), 369387.

Bullough, R. V., Young, J., Erickson, L., Birrell, J. R., Clark, D. C., Egan, M. W., ... Smith, G. (2002). Rethinking field experience: Partnership teaching versus single-placement teaching. Journal of Teacher Education, 53, 68-80. https:// doi.org/10.1177/0022487102053001007.

Bybee, R. W. (2010). Advancing STEM education: A 2020 vision. Technology and Engineering Teacher, 70(1), 30.

Campbell, P. F. (1996). Empowering children and teachers in the elementary mathematics class- rooms of urban schools. Urban Education, 30, 449-475.

Campbell, P. F., \& Malkus, N. N. (2011). The impact of elementary mathematics coaches on student achievement. The Elementary School Journal, 111(3), 430452. https://doi.org/10.1086/657654.

Charmaz, K. (2006). Constructing grounded theory. London: SAGE.

Chia, R. (2000). Discourse analysis as organizational analysis. Organization, 7(3), $513-518$.

Coburn, C. E. (2001). Collective sensemaking about reading: How teachers mediate reading policy in their professional communities. Educational Evaluation and Policy Analysis, 23(2), 145-170. https://doi.org/10.3102/ 01623737023002145 .

Coburn, C. E. (2004). Beyond decoupling: Rethinking the relationship between the institutional environment and the classroom. Sociology of Education, 77(3), 211-244. https://doi.org/10.1177/003804070407700302.

Coburn, C. E., \& Woulfin, S. L. (2012). Reading coaches and the relationship between policy and practice. Reading Research Quarterly, 47(1), 5-30.

Cohen, D. K., \& Hill, H. C. (2008). Learning policy: When state education reform works. New Haven \& London: Yale University Press.

Cohen, L., Manion, L., \& Morrison, K. (2007). Research methods in education. New York: Routledge.

Costa, A. L., \& Garmston, R. J. (1994). Cognitive coaching: A foundation for renaissance schools. Norwood: Christopher-Gordon.

Desimone, L. M., \& Pak, K. (2017). Instructional coaching as high-quality professional development. Theory Into Practice, 56, 3-12. https://doi.org/10. 1080/00405841.2016.1241947.

Deussen, T., Coskie, T., Robinson, L., \& Autio, E. (2007). Coach" can mean many things: Five categories of literacy coaches in Reading First. Washington, DC: National Center for Education Evaluation and Regional Assistance, Institute of Education Sciences, US Department of Education.

Dewey, J. (1933). How we think: A restatement of the reflective thinking to the educative process. Boston: Heath.

Dey, I. (1993). Qualitative data analysis. London: Routledge. 
Fielding, N., \& Fielding, J. (1986). Linking Data. Beverly Hills: Sage.

Fullan, M., \& Knight, J. (2011). Coaches as system leaders. Educational Leadership, 69(2), 50-53.

Gallucci, C., Lare, M. D. V., Yoon, I. H., \& Boatright, B. (2010). Instructional coaching: Building theory about the role and organizational support for professional learning. American Educational Research Journal, 47(4), 919-963.

Giamellaro, M., \& Siegel, D. R. (2018). Coaching teachers to implement innovations in STEM. Teaching and Teacher Education, 76, 25-38.

Gibbons, L. K., \& Cobb, P. A. (2017). Examining content-focused coaching knowledge and practices implicated in designing coaching activities. Elementary School Journal, 117(2), 237-259.

Gibbons, L. K., Kazemi, E., \& Lewis, R. M. (2017). Developing collective capacity to improve mathematics instruction: Coaching as a lever for school-wide improvement. The Journal of Mathematical Behavior, 46, 231-250.

Glaser, B., \& Strauss, A. (1967). The discovery of grounded theory: Strategies for qualitative research, (p. 81). London: Wiedenfeld and Nicholson.

Griffith, G., \& Scharmann, L. (2008). Initial impacts of no child left behind on elementary science education. Journal of Elementary Science Education, 20(3), 35-48.

International Reading Association (2004). The role and qualifications of the reading coach in the United States. Newark: International Reading Association Retrieved December 5, 2018, from https://www.literacyworldwide.org/docs/ default-source/where-we-stand/reading-coach-position-statement.pdf?sfvrsn= f44ea18e_6.

Ippolito, J. (2010). Three ways that literacy coaches balance responsive and directive relationships with teachers. The Elementary School Journal, 111(1), 164-190.

Jacobs, J., Boardman, A., Potvin, A., \& Wang, C. (2018). Understanding teacher resistance to instructional coaching. Professional Development in Education, 44(5), 690-703.

Ketelaar, E., Beijaard, D., Boshuizen, H. P. A., \& Den Brok, P. J. (2012). Teachers' positioning towards an educational innovation in the light of ownership sense-making and agency. Teaching and Teacher Education, 28(2), 273e282. https://doi.org/10.1016/j.tate.2011.10.004.

Killion, J. P., \& Todnem, G. R. (1991). A process for personal theory building. Educational Leadership, 48(6), 14-16.

Knight, J. (2007). Instructional coaching: A partnership approach to improving instruction. Thousand Oaks: Corwin Press.

Laxton, K. E. (2016). Implementing the next generation science standards: How instructional coaches mediate standards-based educational reforms to teacher practice (doctoral dissertation).

Lofthouse, R. (2019). Coaching in education: A professional development process in formation. Professional Development in Education, 45(1), 33-45.

Lord, B., Cress, K., \& Miller, B. (2008). Teacher leadership in support of large-scale mathematics and science education reform. In M. M. Mangin, \& S. R. Stoelinga (Eds.), Effective teacher leadership: Using research to inform and reform, (pp. 55-76). New York: Teachers College Press.

Majors, Y. (2007). Narrations of cross cultural encounters as interpretative frames for reading word and world. Discourse \& Society, 18, 479-506.

Mangin, M., \& Dunsmore, K. (2015). How the framing of instructional coaching as a lever for systematic or individual reform influences enactment of coaching. Educational Administration Quarterly, 51(2), 179-213.

Marco-Bujosa, L. M., \& Levy, A. J. (2016). Caught in the balance: An organizational analysis of science teaching in schools with elementary science specialists. Science Education, 100(6), 983-1008.

McFadden, J. (2015). Teachers as designers: The iterative process of curriculum design focused on STEM integration. Retrieved from the University of Minnesota Digital Conservancy, http://hdl.handle.net/11299/175257.

McFadden, J. (2019). Transitions in the perpetual beta of NGSS: One science teacher's beliefs and attempts for instructional change, 1-30. Journal of Science Teacher Education. https://doi.org/10.1080/1046560X.2018.1559559.

McFadden, J., \& Roehrig, G. H. (2017). Exploring teacher design team endeavors while creating an elementary-focused STEM-integrated curriculum. International Journal of STEM Education, 4(1), 21.

Merriam, S. B. (2009). Qualitative research: a guide to design and implementation. San Francisco: Wiley.

Merriam, S. B., \& Tisdell, E. J. (2015). Qualitative research: A guide to design and implementation. San Francisco: Wiley.

Metz, K. (2008). Narrowing the gulf between the practices of science and the elementary school classroom. Elementary School Journal, 109, 138-161.

Moore, T. J., Glancy, A. W. Tank, K. M., Kersten, J. A., Smith, K. A., \& Stohlmann, M. S. (2014). A framework for quality K-12 engineering education: Research and development. Journal of Pre-College Engineering Education Research (J-PEER), 4(1), 2.

Moore, T. J., Tank, K. M., Glancy, A. W., \& Kersten, J. A. (2015). NGSS and the landscape of engineering in $\mathrm{K}-12$ state science standards. Journal of Research in Science Teaching, 52(3), 296-318.

Mudzimiri, R., Burroughs, E. A., Luebeck, J., Sutton, J., \& Yopp, D. (2014). A look inside mathematics coaching: Roles, content, and dynamics. Education Policy Analysis Archives, 22(53), n53.

Olson, J. K., Tippett, C. D., Milford, T. M., Ohana, C., \& Clough, M. P. (2015). Science teacher preparation in a north American context. Journal of Science Teacher Education, 26(1), 7-28.

Osterman, K. F., \& Kottkamp, R. B. (1993). Reflective practice for educators. Newbury Park: Corwin Press.

Patton, M. Q. (2002). Qualitative research \& evaluation methods. London and New Delhi: SAGE.

Robertson, D. A., Ford-Connors, E., Frahm, T., Bock, K., Paratore, J. R. (2019). Unpacking productive coaching interactions: Identifying coaching approaches that supports instructional uptake. Professional Development in Education. Advance online publication. https://doi.org/10.1080/19415257.2019.1634628.

Schauble, L., Klopfer, L. E., \& Raghavan, K. (1991). Students' transition from an engineering model to a science model of experimentation. Journal of Research in Science Teaching, 28(9), 859-882.

Schön, D. A. (1987). Educating the reflective practitioner, (p. 27). San Francisco: Jossey-Bass.

Spillane, J. P. (2000). Cognition and policy implementation: District policymakers and the reform of mathematics education. Cognition and Instruction, 18(2), $141-179$.

Spillane, J. P., Hopkins, M., \& Sweet, T. M. (2017). School district educational infrastructure and change at scale: Teacher peer interactions and their beliefs about mathematics instruction. American Educational Research Journal (Articles In Press).

Spillane, J. P., Reiser, B. J., \& Reimer, T. (2002). Policy implementation and cognition: Reframing and refocusing implementation research. Review of Educational Research, 72(3), 387-431.

Star, S. L., \& Griesemer, J. R. (1989). Institutional ecology, 'translations' and boundary objects: Amateurs and professionals in Berkeley's museum of vertebrate zoology, 1907-39. Social Studies of Science, 19(3), 387-420.

Tatar, D. (2007). The design tensions framework. Human-Computer Interaction, 22, 413-451.

Trygstad, P. J. (2013). 2012 national survey of science and mathematics education: Status of elementary school science. Horizon Research, Inc.

Van Driel, J. H., Beijaard, D., \& Verloop, N. (2001). Professional development and reform in science education: The role of teachers' practical knowledge. Journal of Research in Science Teaching, 38(2), 137-158.

Weick, K. E. (1995). Sensemaking in Organizations. Thousand Oaks: Sage.

Weick, K. E., Sutcliffe, K. M., \& Obstfeld, D. (2005). Organizing and the process of sensemaking. Organization Science, 16(4), 409-421.

Wiggins, G., \& McTighe, J. (1998). Understanding by design. Alexandria: ASCD.

Wiggins, G. P., \& McTighe, J. (2011). The understanding by design guide to creating high-quality units. Alexandria: ASCD.

Woulfin, S. L., \& Rigby, J. G. (2017). Coaching for coherence: How instructional coaches lead change in the evaluation era. Educational Researcher, 46(6), 323328

Yoon, K. S., Duncan, T., Lee, S. W. Y., Scarloss, B., \& Shapley, K. L. (2007). Reviewing the evidence on how teacher professional development affects student achievement. Washington, DC: US Department of Education, Institute of Education Sciences, National Center for Educational Evaluation and Regional Assistance.

York-Barr, J., Sommers, W. A., \& Ghere, G. S. (2006). Reflective practice to improve schools, (2nd ed.). Thousand Oaks: Corwin Press.

\section{Publisher's Note}

Springer Nature remains neutral with regard to jurisdictional claims in published maps and institutional affiliations. 